\title{
Responding \\ First as a Leading Power
}

\section{Constantino Xavier Carnegie India}

The emerging concept of India as a "first responder" reflects the country's growing capability and increasing willingness to assume the role of a leading power. By contributing its resources to prevent or mitigate regional and international crises, India is demonstrating its commitment as a responsible actor in the international order. Beyond narrow self-interest, such contributions help project India's soft power abroad and portray India in a positive light. They also reflect India's expanding sphere of influence and capacity to shape events abroad.

The international order is facing a variety of transnational challenges that occasionally erupt into acute crises. Whether it is a natural catastrophe, an Internet disruption, or a sudden financial shock, the repercussions are often massive, with regional and global implications. This is where individual states must take immediate action, to mitigate the crisis impact and avoid further escalation. By taking the lead, they are providing a public good to the international order, supporting smaller or less capable states in dire need of assistance.

As the Indian economy surges on and the country emerges as one of the key actors in the international order, expectations are consequently growing about India's capacity to provide such support as a first responder to crises beyond its borders. Commenting on this rising role, Foreign Secretary Dr. S. Jaishankar thus emphasizes that India's foreign policy dimension is "to aspire to be a leading power, rather than just a balancing power ... (and) a willingness to shoulder greater global responsibilities".

While the concept of "first responder" has generally been interpreted quite narrowly, focusing on humanitarian disasters, a broader definition illustrates how India has played a crucial role in assuming these "global responsibilities" by responding to a variety of crises in its neighbourhood and beyond. This is particularly apparent in seven issue-areas. 


\section{Natural disasters}

When the forces of nature unleash their fury on South Asia, the Indian government and military forces have played a critical role in supporting neighbouring countries in relief operations. After the 2004 tsunami, India deployed 14 Navy vessels, nearly 1,000 military personnel and several dozen helicopters and airplanes to Sri Lanka. In 2007, in the aftermath of cyclone Sidr, India was one of the few countries allowed to provide relief to Myanmar and provided critical rice supplies to address food emergencies there. In 2015, less than six hours after Nepal was rattled by a tragic earthquake taking almost 9,000 lives, the Indian Air Force flew in National Disaster Response Force (NDRF) rescue team. Over the next days, India lead on the ground, landing 32 flights with 520 tonnes of relief and more than fifty medical, Army engineering and other rescue operation teams. In 2014, the Indian Navy was the first to arrive in the Madives to provide fresh drinking water to more than 150,000 of its citizens facing an acute supply crisis. More recently, in response to Cyclone More (2017), India was the first to respond to the devastating floods in Sri Lanka and Bangladesh. As reflected in relief provided to Pakistan in 2005 and 2010, Indian support transcends political considerations and is driven by a deep humanitarian drive .

\section{Expatriate evacuation operations}

When crises erupt abroad, India is often the first on the ground to protect the lives and assets of its nationals. By mobilizing its consular officers, New Delhi has also provided safe evacuation to citizens from other countries. In 2015, for example, India extricated almost 2,000 nationals from 48 different countries, including many from the European Union, the United States and neighbouring countries. The Ministry of External Affairs, Air India, and the Navy and Air Force have emerged as key actors in conflict zones, especially in the Indian Ocean and Gulf region, normally operating as first responders coming to the rescue of thousands of foreign nationals in distress.

\section{Non-traditional security challenges}

The Indian Navy has emerged as the Indian Ocean's default first responder to non-traditional security challenges. To combat piracy in the Gulf of Aden since 2008, it deployed almost thirty warships that have escorted more than 1500 ships and thwarted around thirty piracy attempts. India was a founder-member of the Contact Group on Piracy off the Coast of Somalia (CGPCS) and has taken a lead role in coordination efforts among different naval forces in the region. When airplanes or ships go missing in its extended 
neighbourhood, India has often been among the first responders to participate in search and rescue missions. In 2014, the Indian Coast Guard deployed around the Andaman and Nicobar Islands in initial efforts to locate the missing Malaysian Airlines flight MH370 .

\section{Post-conflict relief and rehabilitation}

India has often taken the lead in supporting countries going through postconflict processes which require expert resources and significant funding. After the end of the armed conflict in Sri Lanka, in 2009, India provided more than USD one billion worth in lines of credit and grants for projects in education, health, transport connectivity, and training. Focusing on relief, rehabilitation and reconstruction, India's early efforts played a crucial role in facilitating Nepal, Sri Lanka, and Afghanistan's return to normalcy years of violent conflict. As one of the largest contributors to United Nations peacekeeping missions, India's "blue helmets" have also served as first responders to mitigate dozens of conflicts around the world, leading efforts on the ground to facilitate stabilization and reconstruction.

\section{Regime support}

Whenever friendly governments face the risk of a coup or instability threatening regional security, India has often stepped in as a first support responder. In 1988, for example, in response to a request from the Maldives, India activated Operation Cactus to deploy its military and ensure regime continuity in Male. Located in one of the world's most conflict-ridden regions, whenever requested by neighbouring countries, India has also played a constructive role in offering its mediation services to ensure peaceful and inclusive settlements. New Delhi is also a democratic first responder, deploying expert technical support to assist transitioning democracies to design their new constitutions and hold free and fair elections .

\section{Financial assistance}

India plays a little-known but crucial role as a first responder in the region to support friendly governments facing financial crises. Under a special currency swap mechanism instituted in 2012, the Reserve Bank of India has provided critical assistance to the governments of Bhutan, Maldives and Sri Lanka whenever they face foreign currency liquidity shortages. By coming to the rescue of their respective monetary authorities, New Delhi has demonstrated its commitment to financial stability and economic growth in the region, strengthening governance to wither crises. 


\section{Refugee flows}

Whenever people fear for their lives in South Asia, they often look up to India first. India has consistently provided an emergency safe haven for refugee and minority populations from across South Asia. Whether they are affected by violent conflict or any type of persecution, most displaced people's routes to safety pass through India, taking advantage of its default open doors policy. Since 1947, this includes people from Tibet, East Pakistan, Afghanistan, Burma/Myanmar, and Sri Lanka, leading the current UN Secretary General to speak of India's refugee policy as a model for other countries.

India's contribution as a first responder in these areas above will continue to increase as its economy grows in size and openness. In his message to the heads of Indian missions abroad, in 2015, Prime Minister Modi thus "urged them to use this unique opportunity to help India position itself in a leading role, rather than just a balancing force, globally."[2] As India expands its horizons, it will keep stepping up to take the lead where other countries are reluctant, unwilling or incapable to do so .

This first respondent tradition must be further studied and promoted, because it reflects India's deep commitment to assume a driving role in the international order. And it will also have to be endowed with adequate resources and capabilities for India to move even quicker and farther beyond its borders. 